$1-1-2018$

\title{
Between Economic Planning and Market Competition: Institutional Law and Economics in the US
}

\author{
Laura Phillips Sawyer \\ Associate Professor University of Georgia School of Law, LPhillipsSawyer@uga.edu
}

p bepress

\section{Repository Citation}

Laura Phillips Sawyer, Between Economic Planning and Market Competition: Institutional Law and Economics in the US (2018),

Available at: https://digitalcommons.law.uga.edu/fac_artchop/1367

This Book Chapter is brought to you for free and open access by the Faculty Scholarship at Digital Commons @ University of Georgia School of Law. It has been accepted for inclusion in Scholarly Works by an authorized administrator of Digital Commons @ University of Georgia School of Law. Please share how you have benefited from this access For more information, please contact tstriepe@uga.edu. 


\section{Between Economic Planning and Market Competition: Institutional Law and Economics in the US}

\section{Laura Phillips Sawyer}

In 1926 John Maurice Clark published a seminal text in institutionalist economics, Social Control of Business, surveying the ways in which business was subject to control by a variety of formal and informal constraints. ${ }^{1}$ The text rejected mainstream ideas in neoclassical political economy by explaining how individual self-interest and competition could be manipulated not only through legal rules but also by custom, habit, codes of ethics, and morals. Representative of the institutionalist movement, Clark discarded presumptions of an individualistic economy based on market competition. Instead, he posited that long-term public goals of prosperity and equity could be achieved through the public and private study of "industry itself," which existed "on the frontier where new policies are being worked out." ${ }^{2}$ The book fused the development of the regulatory state, giving particular attention to administrative law, with self-regulation by businesses and trade associations. Both public

\footnotetext{
L. Phillips Sawyer $(\square)$

Harvard Business School, Boston, USA

e-mail: LSawyer@hbs.edu

(C) The Author(s) 2018 
and private regulations, he argued, advanced codes of conduct to standardize business activities and control competitive practices. Building on the work of Richard Ely, John Commons, and Dean Roscoe Pound, Clark's Social Control of Business extended progressive liberals' initiatives for regulatory state expansion through administrative agencies and it advanced private rulemaking by trade associations as a complement to the development of mandatory public regulation.

Social Control of Business epitomized the first great law and economics movement's challenge to the neoclassical paradigm of academic research and public policy. ${ }^{3}$ Rather than pursuing a policy agenda based on a singular model of human behavior or industrial order, the institutionalists believed that social science research should guide policy makers in shaping rules and regulations according to the particular structure of a given industry. The purpose of industry-specific studies was twofold: to understand the economic dynamics of an industry, giving especial attention to social costs or negative externalities, and to construct a detailed account of the macroeconomy as a whole. That approach resulted in a slew of studies and policies that many critics have said amounted to little more than questioning of orthodox economics, rather than a coherent research agenda. Institutional economics, in turn, has been largely dismissed and overlooked by mainstream economic and policy history because of its limited duration in the academy and its very diverse policy prescriptions. ${ }^{4}$ Dismissing the influence of institutionalism obscures the intellectual origins and social purposes of the 1920s "new economics" in academic research, regulatory policy, and private self-regulation.

This essay argues that one of the central tenets of institutionalist law and economics - the social control of business-helped structure the research and planning agendas of administrative agencies, such as the Department of Commerce and the Federal Trade Commission (FTC), as well as private research organizations, including Harvard Business School (HBS), the National Bureau of Economic Research (NBER), and the Social Science Research Council (SSRC). ${ }^{5}$ The motivation toward social control united progressive liberal economists who sought to reform not only academic research methods but also policy-making outcomes. Their experiences during WWI with domestic economic 
planning motivated the institutionalists toward postwar collaboration with government officials, regulators, and private research institutes. By the mid-1920s, the first great law and economics movement had embedded a long-term research agenda within both public administrative agencies and private research institutes, both of which pursued social science research in economic planning.

\section{Interwar Institutional Economics}

At the close of the First World War, the American Economic Association (AEA) convened a small, one-day conference to discuss various aspects of postwar recovery. Sessions covered monetary stability, maintenance of international peace, price fixing during peacetime, and the future of agricultural policies. ${ }^{6}$ At that conference, Walton Hamilton coined the term "institutionalist economics" to signal a break with existing US economic thought and policy. In turn, Hamilton emerged as the initial spokesperson for a group of progressive liberal economists who believed neoclassical economics, theory, and regulation could not address the new economic realities of the postwar world. Cosponsored by the American Sociological Society, his panel, entitled "Economic Theory," stood apart from the rest. At that panel, Walton Hamilton laid out a new agenda not only for economic theory and research methods but also for economic regulation. ${ }^{7}$

Hamilton's paper, which appeared in the following year's American Economic Review, surveyed the state of the discipline and argued that neoclassical economics' reliance on subjective value theory had led the discipline away from critical analysis and toward becoming nothing more than status quo apologists. "Only in recent years has value theory escaped a formal association with laissez faire [but] now even its most positive statements bear in such terms as 'utility' and 'productivity' and in the wording of principles [belie] implications about the worthwhileness of prevailing arrangements." was not wholly laissez faire, Hamilton conceded; however, the subjective 
theory of value relied upon the premise of free competition and individual choice that Hamilton questioned. The world had changed with industrialization and world war, Hamilton and many other progressive economists argued, bringing new social problems and greater demand for control of powerful economic interests. Institutional economics, he offered as an alternative, was "concerned with industry in relation to human well-being." 10

Economics had taken for granted the institutions-derived from custom, habit, and formal legal structures-that ordered economic relationships. Hamilton argued that because "institutions are social arrangements capable of change rather than obstinate natural phenomena," economics "should be relevant to the modern problem of control." 11 Whereas neoclassical economists' focus on value theory had been "derived from the classical doctrine of organization of industry [based] upon the principles of free competition," the institutionalist research agenda began not with the presumption of perfect competition but rather focused on the inherent malleability of economic relationships. ${ }^{12}$ Rather than seeking out "economics statics" and equilibria to explain the "immutable" laws of industrial economies, Hamilton envisioned administrative agencies and private initiatives capable of identifying the "economic dynamics" that created and distributed value. Partnership between business, government, and the social sciences could temper competition and improve the distribution of wealth. Those new administrative bodies could collaborate with firms and trade associations so as to gather information and help shape business interactions through "conscious control." The purpose of the "social control" of business would be to improve not only efficiencies but also, perhaps more importantly, the distribution of wealth and resources.

For Hamilton, as with the institutionalist movement more generally, not all market competition improved social welfare or maximized efficiencies. In response, his life's work was dedicated to the pursuit of economic models and legal reforms that employed new management techniques for a public purpose. Others in this movement-including Wesley Claire Mitchell, Sumner Slichter, Leo Wiloman, Dexter Keezer, Stacy May, and Morris Copeland-were also concerned with the responsibilities of business to society. ${ }^{13}$ Their great insight was that 
neoclassical economics had failed to incorporate ethical or societal considerations into its economic models, instead presuming that free competition necessarily maximized aggregate welfare.

Several leading institutional economists pioneered studies in business cycles, investigating the causes of economic booms and busts as well as the social costs of economic adjustments. Wesley Mitchell, who developed the most influential theory of business cycles in 1913, provided a trenchant critique of neoclassical value theory and its presumption of rational decision making. ${ }^{14}$ Borrowing from Thorstein Veblen's criticism of mainstream economics' portrayal of man as a "lightning calculator of pleasure and pain," Mitchell argued that such a hedonistic conception of man failed to consider the psychological or evolutionary influences on decision making. ${ }^{15}$ Rather than fixing prices according to market supply and demand, for example, businesspeople could be driven to "ruinous competition," wherein prices fall below costs, by their desire to destroy rivals. Not only could such behavior reduce competition and facilitate market consolidation, it also increased unemployment, drove down wages, and facilitated underconsumption. ${ }^{16}$ Mitchell also examined banks' pro-cyclical lending, businesses' over-leveraging during a boom, and the concomitant bankruptcies characteristic of an economic bust or recession. Mitchell's work on business cycles and prescriptions for macroeconomic "social experiments" to mitigate downturns proved influential during the brief but sharp postwar recession.

Clark's Social Control of Business built upon Mitchell's study of business cycles by emphasizing that private rights alone could not satisfy the needs of a complex industrial society. Rather than individuals guiding business decisions, Clark presented six case studies that examined formal industrial regulations, extralegal codes of ethics used by business and professional associations, and informal union rules. In his final chapter, "If I were Dictator," he reflected on how those overlapping rules and mechanisms might be employed to negate the negative externalities of industrial production, including waste of natural resources, unemployment, and underconsumption. Critically, however, Clark believed that the administrative state must partner with business, professional, and labor organizations rather than dictate state-led or topdown regulations. He intended that partnership to preserve the positive 
benefits of the price mechanism, while also guiding closer coordination between business and government. ${ }^{17}$

The institutionalists appealed to the wider world of progressive reform and political discourse. Despite their critics, they developed several programs for the collection, tabulation, and dissemination of business statistics by appealing to reformers, business groups, and regulators. First, they built on the progressive liberal tradition emerging at the turn of the century that emphasized the interdependencies created by modern industrialization and urbanization. The institutionalists came from a cohort of pragmatic social reformers, such as John Dewey, Herbert Croly, and Walter Lippmann, who supported the expansion of state power to better citizens' lives. Institutionalists built on those impulses and contributed a technocratic vision of expert-led governance through administrative state agencies and trade associations. Secondly, the institutionalists also appealed to a diverse set of businesspeople seeking to rationalize business management practices-sometimes through topdown regulation but more often through deliberative organizations outside of government. Finally, their empirical approach attracted the attention of both business associations and state agencies, creating new collaborations between academic economists, private commercial associations, and government regulators. ${ }^{18}$

In their rejection of universal principles and generalizable economic rules, the institutionalists preferred deductive logic, which required industry-specific studies to evaluate the changing processes of price and wage setting, patterns of employment, and procedures to manage competitive markets. In order to paint "a picture of the pragmatic reality called industry," they pursued present business statistics as well as historical data in search of social and economic trends. ${ }^{19}$ Then as now, the great strength and purpose of the institutionalists' research agenda also became its Achilles' heel. The main critique against the institutionalists was their lack of a coherent research method or any generalizable theory of value or competition. ${ }^{20}$ But, of course, this was precisely their point-neither economic conditions nor their governing institutions remained static, and the purpose of the social sciences should be to understand how those institutional constraints could be used to govern dynamic economies. 


\section{Social Control and the Administrative State}

The institutionalists' critique of neoclassical economics and law reflected a pervasive reconsideration of market competition that had resulted from the economic realities of a changing industrial order. Prior to the wartime experience of a coordinated market economy, formal legal rules and administrative agencies had been created to manage a rapidly changing economy. Corporate consolidations around the turn of the century had been met with the consternation of farmers, small proprietors, and laborers who felt disenfranchised from the economic gains made by corporate capitalists. Those social dislocations that accompanied industrialization and urbanization informed the regulatory politics of the anti-monopoly movement, which feared not only the consolidation of market power suppressing competitive markets but also the corresponding malady of undue political influence corrupting democratic political processes. In turn, the passage of the Sherman Antitrust Act of 1890 forbade restraints of trade and monopolization in interstate commerce. Yet, it failed to stem the growth of large-scale corporations or abuses of dominant firm position, such as predatory pricing. Additionally, the US Supreme Court's strict interpretation of the law occluded any associational activities that could be construed as collusive and, thereby, the Court further incentivized vertical consolidation. The institutionalists provided economic reasoning for a political and regulatory movement to further revise the rules of competition through administrative experts, rather than legislative processes. They endorsed new administrative controls intended to manage competitive processes so as to reduce social costs and market externalities associated with these corporate consolidations and market fluctuations.

Although the passage of the Federal Trade Commission (FTC) and Clayton Acts of 1914 failed to settle the uncertainty of competition policy, these did empower an administrative agency to review and prosecute anticompetitive business activities. That legislation created the FTC, which prohibited price discrimination, tying contracts, interlocking directorates, and unfair methods of competition, and also exempted labor unions from antitrust prosecution. President Wilson, who signed 
the act, asked the US Chamber of Commerce (USCC) to participate in an experiment with the FTC to "match all the facts of business throughout the country and to see the vast and consistent pattern of it," just as the Department of Agriculture did for farmers. ${ }^{21}$ Joseph Davies, Commissioner of Corporations at the Department of Commerce, explained that the purpose of the FTC was "to convert the anarchy of unlicensed competition into a condition under law of competitive liberty, which will preserve those seeds of individual initiative and enterprise." 22 The liberal democratic goals espoused by the FTC mirrored the nascent formation of institutionalist research and policy agendas.

During its first years, FTC commissioners promoted uniform cost accounting and information sharing on industrial trade statistics in efforts to promote standardized business practices largely through trade associations and minimal public oversight. FTC Commissioner Edward Hurley, former president of the Illinois Manufacturers' Association, explained that reliable cost information must be the first step in rationalizing intra- and inter-business practices. ${ }^{23}$ In an FTC pamphlet circulated to 230,000 businesses and commercial associations, for example, Hurley explained that rather than focusing only on sales volume, managers should determine the costs and revenues of each specific product line and distribute the overhead expenses accordingly. The manual demonstrated bookkeeping methods to actuate product line expense reports. ${ }^{24}$

Uniform cost accounting standardized methods to calculate prices and, thereby, influenced what constituted a fair price according to both the informal rules promulgated by trade associations and the standards enforced through FTC prosecutions. The notion of an enforceable standard of fair competition required basic bookkeeping before the FTC could sufficiently regulate trade practices or act as a clearinghouse for industry information. Training "industrial secretaries" became a focal point of USCC meetings. Paul Cherington, an economist and marketing professor at the Harvard Graduate School of Business Administration, as it was then known, led a special committee on retail prices and cost accounting for the Chamber. For Cherington and other progressive economists and businesspeople, unfair competition carried a destructive edge that cut against independent proprietors. "Destructive" 
or "cutthroat" practices included secret rebates given to large-scale retailers, sales below cost, and loss leader advertising. These activities, they argued, threatened the long-term viability of competitive markets for quality consumer durables by reducing the number of competitors. ${ }^{25}$ Cherington, along with Paul Nystrom (a Wisconsin-educated economist), embraced Brandeisian logic that valued a decentralized economic order and endorsed antitrust exemptions for associations of small proprietors.

Although the institutionalists did not promote restrictions on firm size or scope, they shared progressive liberals' fears that concentrated economic power might lead to predatory practices and monopoly. Searching for a middle ground between conceding to oligopolies of large firms and preserving inefficient firms, the institutionalists' publicprivate regulatory approach to protecting competitive markets reflected the policy preferences of Louis Brandeis, an architect of the FTC. Those efforts to manage market competition through trade association rulemaking that often bordered on collusive behavior also provoked the ire of some dominant firms. For example, Percy Straus of Macy's, a chain department store based in New York, led efforts against Resale Price Maintenance, a coordinating device used by small and independent proprietors to standardize brand name prices across all retail outlets. ${ }^{26}$

The administrative reordering of public and private interests informed not only President Wilson's stance on domestic competition policy but also mobilization efforts during the First World War. Both progressive economists and leading businesspeople participated in wartime planning efforts, many of whom became advocates for codes of fair competition and greater collaboration between government and business to rationalize markets through standardized business practices and information sharing. Yet, the wartime experience did not create a fully institutionalized order. Initially, smaller businesses had begun efforts at voluntary war preparedness, and later, Bernard Baruch, chairman of the War Industries Board (WIB), led efforts for "cooperative committees of industry." 27 The WIB did not authorize outright price fixing, although military purchasing bureaus enforced price restrictions. It left an ambiguous legacy - it relied on the voluntary collaboration of trade associations and government regulators, creating neither a fully coordinated nor a cartelized economy. 
The war's legacy strengthened the appeal of public-private management of competitive industries as a viable model for American regulation and antitrust reform, especially for small and medium-sized firms for whom corporate consolidations appeared most threatening. The war's celebrated legacy of the social control of business galvanized both institutional economists and administrative regulators interested in rationalizing business interactions to institute social and economic reforms. ${ }^{28}$ But the FTC's renewed attention to trade association activities and policing competitive business practices almost immediately provoked a jurisdictional dispute with the Court, regarding which branch of government could determine what constituted unfair trade practices. ${ }^{29}$ Despite the Court's ruling that narrowed the FTC's authority, businesspeople within the USCC and regulators at the FTC and Department of Commerce continued to pursue rulemaking authority through administrative interventions.

The wartime experience strengthened the institutionalists' research agenda and broadened the appeal of private businesses partnering with public administrative agencies as beneficial to both private concerns and public interest. This confluence of factors helped to rework the conceptual category of market competition. By the 1920s, a distinctly American view of "new economics" captured prominent economic departments, business schools, government bureaus, and USCC debates. Advocates envisioned a system of cooperative capitalism that managed production and consumption so as to maintain price stability, facilitate innovation, and ensure fair play among competitors.

Through the 1920s, this program for managing American competition became part of the administrative role of the Department of Commerce and FTC. With Herbert Hoover at the helm of the Department of Commerce, he took over many of the standardization, conservation, and information-sharing efforts first initiated by the WIB and carried these into peacetime. In his role as US Food Administrator during the war, Hoover had led a team of businesspeople and economic experts to coordinate production and distribution of foodstuffs abroad. "Food will win the war," he promised the USCC. ${ }^{30}$ Indeed the widespread success of wartime industry coordination helped popularize the associational movement, not for price controls per se but certainly 
for the continuation of information sharing and standardization programs. In July of 1921, the Commerce Department began publishing a monthly Survey of Current Business, a collection of industry statistics on bids, prices, quantities sold, and orders. The Survey lent authority to the "open price association" model, which had received support from Louis Brandeis and Arthur Jerome Eddy a decade earlier as a method by which trade associations might mitigate the so-called ruinous competition through mandatory information sharing. ${ }^{31}$ Similarly, Hoover helped reform the Census Bureau to gather and disseminate economic statistics for both private businesses and public regulators. The Government Printing Office published endless pamphlets and manuals on cost accounting, industry standards and statistics, and business cycle reports. $^{32}$

Hoover's influence reached beyond the Department of Commerce as well, extending to the FTC and Department of Justice by mid-decade. Under his leadership, a series of government-sponsored conferences brought together businesspeople, public officials, and reformers to address a range of business problems, including overfishing Alaskan salmon, oil by-products in the Chesapeake Bay, and highway safety. By the mid-1920s, the FTC began hosting industry-wide trade practice conferences, building on the engineer's conviction that standardized practices could eliminate waste in production methods and employment fluctuations. These conferences were intended to rationalize business practices and set standards for what constituted fair competition.

Hoover's close economic aide, Wesley Mitchell, urged the Commerce Secretary to consider how these social costs of doing business were transferred onto the public at large. ${ }^{33}$ Hoover's interest in reducing waste and rationalizing industry coincided with Mitchell's institutional agenda to reduce the costs of industry. Although Hoover did not endorse direct economic interventions in most cases, he expanded the federal government's sphere of influence over business through data collection, tabulation, and distribution. Moreover, as chairman of President Harding's Committee on Recent Economic Changes, he adopted Mitchell's language of "social experimentation" to alleviate unemployment endemic to business cycle swings. Although Hoover agreed that capriciousness of the market led to labor unrest and 
unemployment, transferring social costs from business to society, he was not prepared to accept institutionalists' proposed labor legislation. Nevertheless, the fact-finding missions of the Committee on Recent Economic Changes as well as the capacity building of administrative agencies influenced the range of policy proposals available to President Franklin Roosevelt's first administration.

Despite his initial efforts, Hoover could not stifle Department of Justice prosecutions of such loose combinations under Attorney General Harry Daugherty's leadership; however, Hoover did outlast him. When Daugherty stepped down in April 1924, President Calvin Coolidge nominated Harlan Fiske Stone to replace him. A friend of Hoover and progressive economists alike, Stone, who would join the Supreme Court only a year later, initiated test cases against trade associations in order to clarify what industry cooperation would pass constitutional muster. For example, Stone brought an antitrust suit against the Maple Flooring Manufacturers Association for information sharing on production processes, bids, and output. Then, one year later, as a newly appointed Court Justice, he penned the Court's opinion upholding the association agreements. The trade associations, according to Stone's majority opinion, had collaborated to reduce waste and had also reduced prices, relative to nonmembers. Also, the Court held, the association's collaboration with the Department of Commerce provided important information to the Federal Reserve and other departments of government. ${ }^{34}$ Although the institutionalists had not formalized a theory of public-private management of competitive markets, a shift in the American regulatory system had taken place by the mid-1920s. ${ }^{35}$

\section{Academic Experts and Intermediary Organizations}

The attention given to Hoover's Department of Commerce obscures the role of a wide range of advocates in public service and private research institutes who also fostered a public-private system of managed competition. ${ }^{36}$ The popularity of institutionalist research methods and 
goals to rationalize internal management and stabilize inter-firm competition spread to leading research universities and institutes. Animated by a belief in the responsibility of business to society and the possibility for new forms of social control, a loosely coordinated movement arose across a variety of newly established research organizations, including Harvard Business School (HBS), the National Bureau of Economic Research (NBER), and the Social Science Research Council (SSRC). These private organizations pursued industry-specific studies to better understand competitive practices and the price-cost relationship according to industry-specific production and distribution methods. Studies focused on the methods used to coordinate industrial development through uniform cost accounting, standardized production and grading systems, and codes of ethics affecting prices and wages. Indeed, there was great hope that rationalizing intra-firm management through research-based rules might stem business cycles, reduce waste, and provide a more equitable system of competition, minimizing social costs. These intra-firm management techniques were often codified by trade associations and sanctioned by FTC regulators, particularly when sponsored through FTC trade practice conferences. Ultimately, these research centers helped establish organizational and professional authority by disassociating such coordinating tactics with private selfinterest or cartelization. Instead, research and publicity supported association-based cooperation as an alternative to both free market competition and state socialism.

The Harvard Graduate School of Business Administration promised a new era of business organization and managerial efficiency achieved through expert accountants and managers, which it publicized to the US Chamber of Commerce. For example, Paul Cherington explained, the business school's course "Commercial Organization" had developed its "own system of uniform cost accounting," which "trained recruits" mastered in banking, railroad rate making, commercial law, and general accounting. ${ }^{37}$ Students attended discursive lectures by professors and industry leaders and then performed fieldwork as an apprentice of sorts. The scientific accounting methods of these "commercial secretaries" explained pricing policies and provided important legal defense for price protection policies by a single firm or a group of firms. Instituting 
a uniform system of cost accounting became one of the most important prerequisites to coordinating business group best practices. ${ }^{38}$

The Harvard Bureau of Business Research had been established "for the purpose of assembling and classifying business data and establishing ... standards and principles of business action.” The school employed the institutionalist research methods, and many of its early leaders subscribed the movement's progressive policy agenda. ${ }^{39}$ From its outset, Dean Edwin Gay, a trained institutional economist, complained that "no accounting and statistical standard existed" especially in retail management, where competition between chain stores and independent proprietors frequently drove prices below the latter's costs. The political backlash provoked by highly competitive industries had encouraged campaigns for protective legislation and a sincere questioning of whether or not concentration and consolidation benefited consumers in the long run.

Gay steered Harvard's directors to conduct its first study in the retail distribution of shoes. Given that industry's relatively standardized and stable production methods, retail management techniques could be isolated and analyzed. ${ }^{40}$ The "Harvard System" developed a cooperative framework of information sharing -600 participating shoe retailers from across the country submitted sales data to the Bureau's statisticians, who created standard accounting methods and principles. They measured each store's gross profits, total operating expenses (excluding freight, cartage, and interest), buying expenses, sales force, advertising, deliveries, rent, interest, stockturns per year, and annual sales of the average salesperson. The Bureau, then, calculated percentages for each category and circulated comparative charts to show how the least and most profitable businesses operated. ${ }^{41}$ The data showed how firm management dictated prices and profitability. Additionally, the data provided the requisite information to sufficiently identify predatory practices, which associations might prohibit. Similarly, Edwin Gay later partnered with the progressive liberal business leader, Henry Dennison, to advance voluntary reforms to corporate governance in support of profit-sharing plans and pension plans. ${ }^{42}$ Social science investigations could be used to improve business management techniques as well as to expose the social costs and benefits of competing systems. 
During the war, Mitchell had envisioned creating a nonpartisan institute to provide serviceable social science data for both public and private management purposes; antitrust law, however, presented an obstacle. It was not clear what information-sharing constituted an attempt to restrain trade. ${ }^{43}$ Under Mitchell's guidance, the NBER partnered with the Department of Commerce and the FTC for information gathering purposes. The accumulation and analysis of such knowledge, Mitchell argued, required permanent public and private institutions to support social science research and guide public policies. ${ }^{44}$

That relationship with government continued after the war; at the behest of Secretary of Commerce Herbert Hoover, Mitchell received an invitation to participate in President Warren Harding's Conference on Unemployment in 1921. Mitchell joined the business cycle committee, along with Owen Young (chairman, General Electric), Joseph Defrees (president, Chamber of Commerce), Matthew Woll (American Federation of Labor), Mary Van Kleeck (Russell Sage Foundation). To avoid future economic recessions, the committee's final report called for greater information sharing between business and government for the purpose of private and public planning.

The best service Government can render is to collect the necessary information to show us what the present situation in business is, what current trends are, to collect comparatively simple statistics from a very wide circle of industries, to put it in effective form and then make use of it by the business public. ${ }^{45}$

Mitchell, who had been a founding member of the institutional economics school, was perhaps one of the best experts to reach out to the business community and explain the micro- and macroeconomic benefits of cooperative research, rulemaking, and economic planning. His book, Business Cycles (1913), had famously explained economic downturns as the result of endogenous shocks that reverberated throughout the economy. ${ }^{46} \mathrm{He}$ had categorized the variables that determine profits, revenue, and costs, and he explained how each variable responded to stages of a cycle. Mitchell's study concluded that "during the revivals 
prices of labor rise less than prices of commodities." ${ }^{7} 7$ This wage lag created a problem of underconsumption that could retard recovery.

As a result of his academic work and participation on the conference committee, Mitchell supported "social experimentation" in private and public unemployment insurance programs to protect workers during economic downturns. ${ }^{48}$ While not all conference participants embraced unemployment relief and insurance plans, Mitchell urged Hoover to embrace relief in order to achieve recovery. Hoover took credit for creating unemployment branch offices in states with severe unemployment; those offices then partnered with federal agencies. ${ }^{49}$ The conference recommendations reflected institutionalists' concerns with uncoordinated economic activities leading to problematic social consequences, like unemployment and waste of natural resources, which required government oversight and coordination of private sector business decisions. The final report also brought together multiple disciplines to achieve macroeconomic stability, appealing to economists, businessmen, statisticians, and social workers. Mitchell remained a part of Hoover's Commerce Department, acting as a lead economist to the Advisory Committee on Statistics aiding in the Department's Current Survey. ${ }^{50}$

In addition to the NBER, several other private and university-based research institutes emerged in this period. In 1923, Charles Merriam, a professor of political science, established the Social Science Research Council (SSRC) at the University of Chicago. The SSRC employed similar empirical methods and, by the early 1930s, became influential in national political economy. Like Mitchell, Merriam rejected the rational man theory of value in neoclassical economics. Instead, he pioneered quantitative studies on individual decision making that could be aggregated in order to better understand how democracies think, so to speak. He envisioned these data being particularly useful to political leaders and their social scientist advisors. ${ }^{51}$ Ultimately, he is credited with founding the behavioralist approach to the practice of politics, which, similar to institutionalist economics, employed modern psychology and statistical research to understand individual choice and pluralist decision making. His goal with the SSRC and later organizations, such as the Public Administration Clearing House, was to improve 
government administration through social science research so as to achieve democratic ends, charting a path between free market capitalism and state socialism. ${ }^{52}$ Also like Mitchell, those goals brought him back to federal government service, both within President Hoover's Research Committee on Social Trends, in 1929, and President Franklin Roosevelt's National Planning Board, in 1933. ${ }^{53}$

Each of these organizations brought the social sciences closer to business management and public policy making, though in distinct ways. HBS sought to professionalize business management not only in the pursuit of profits but also toward the public interest. NBER's goal to gather and disseminate micro- and macroeconomic data to mitigate business cycles brought its economists in direct contact with both business leaders and policy makers. Likewise, the SSRC's research agenda focused on minimizing the social costs of American capitalism through economic reforms aimed at raising social minima. Although each attempted to retain its impartiality, the thin line between scientific management and social economic planning blurred as social scientists moved between groups, cross-pollinating ideas and institutions.

For institutionalists like Mitchell, Hamilton, and JM Clark, institutionalism affirmed that business was broadly "affected with a public interest." ${ }^{54}$ Institutionalists also espoused a firm commitment to deliberative processes, following their commitment to social scientific inquiry, economic measurement, and fact-gathering. ${ }^{55}$ From that developed the managerial economics of pricing behavior of firms, macro studies of business cycles, organizational theories of ownership and corporate governance, and public-private designs for competition policy. The theme of social control runs throughout each of these categories of inquiry. The idea of social control of business steered institutionalists to develop government regulation toward socially desirable outcomes. This diverse group chose different routes to that end. Hamilton, for example, joined the Yale Law School and focused his efforts on constitutional arguments to abandon the legal formalism of yesteryear. ${ }^{56} \mathrm{He}$ remained firmly an antitruster who believed in the public-private tradition of managed competition. He reentered government service as an assistant attorney general to Thurman Arnold in 1938. Mitchell continued to 
gather data and direct research initiatives at the NBER and proposed modest indicative planning.

The crisis of the Great Depression created a catalyst for social-political change in the USA, and under these circumstances policy makers, regulators, and business leaders drew from existing paradigms of economic management. The influence of a more radical strand of institutionalists peaked during the First New Deal with the National Industrial Recovery Act, but outright price fixing failed to pass constitutional muster. Nevertheless, institutional economics and the vision of managed competition as a public-private exchange persisted through piecemeal legislation in the Second New Deal. But it was the continued authority of the FTC as the manager of competition, evolving through administrative law rather than statutory mandate, which provided its truly lasting legacy. ${ }^{57}$

Public-private cooperation between regulators and business groupsfor better or worse-has become embedded in American state-building. In addition to various trade associations' success at coordinating industry standards, information sharing on costs and prices, and intra-group monitoring, businesspeople learned that greater political power and legitimacy resulted from collaborating with academics and government officials. But this was not a straightforward "capture" story. ${ }^{58}$ These coalitions promulgated a vision for managed competition that must be understood as resulting from that interwar cooperation. In other words, we cannot understand the interest group story of managed competition without appreciating how an alternative vision of American capitalism resulted from an ongoing exchange between institutional economists, public regulators, and private research institutes. We cannot understand the complexity or contingency of US political economy without recognizing the plurality of visions for American capitalism that rejected free market competition but yet did not embrace state socialism either. Within these interstices, the institutionalists helped build the modern American system of public and private economic governance. 


\section{Notes}

1. John M. Clark, Social Control Business (Chicago: University of Chicago Press, 1926). On institutional economics, see Malcolm Rutherford, The Institutionalist Movement in American Economics, 1918-1947: Science and Social Control (Cambridge: Cambridge University Press, 2011); Geoffrey Martin Hodgson, The Evolution of Institutional Economics: Agency, Structure, and Darwinism in American Institutionalism (New York: Routledge, 2004).

2. Clark, Social Control, 65.

3. Herbert Hovenkamp, Enterprise and American Law, 1836-1937 (Cambridge, MA: Harvard University Press, 1991); Barbara H. Fried, The Progressive Assault on Laissez Faire: Robert Hale and the First Law and Economics Movement (Cambridge, MA: Harvard University Press, 1998).

4. See Mark Blaug, Economic Theory in Retrospect, 4th ed. (Cambridge, 1985); Malcolm Rutherford, "Understanding Institutionalist Economics: 1918-1929," Journal of the History of Economic Thought 22 (2000): $277-$ 308. The conventional history of the institutionalist movement portrays it as disjointed and incoherent; however, Rutherford and other revisionists argue that "institutionalism was associated with a particular research agenda that must, at the time, have seemed full of promise and excitement." Ibid., 278.

5. William J. Novak, The People's Welfare: Law and Regulation in Nineteenth-Century America (Chapel Hill: University of North Carolina Press, 1996); Brian Balogh, A Government Out of Sight: The Mystery of National Authority in Nineteenth-Century America (Cambridge: Cambridge University Press, 2009). Both Balogh and Novak have demonstrated the long-standing public-private tradition of American governance. This paper emphasizes new methods of public-private economic regulation through administrative agencies and trade associations.

6. "Program for the Thirty-First Annual Meeting," American Economic Review 9 (March 1919): 1-4.

7. Rutherford referred to Hamilton's "work on law and economics, industrial organization, and the social control of industry [as] one of the most important lines of institutionalist work." Rutherford, Institutionalist Movement, 12. 
8. Walton H. Hamilton, "The Institutional Approach to Economic Theory," AER 9 (1919): 309-18. The discussants were well-positioned to focus on the postwar adjustments: W.W. Stewart (War Industries Board), L.H. Haney (FTC), and B.M. Anderson, Jr. (National Bank of Commerce).

9. Ibid., 310.

10. Ibid., 311.

11. Ibid., 312-13. "Since the neo-classical doctrine has passed into the inheritance, the formal defense of laissez faire is gone, though it still lingers implicitly in terms and the statement of propositions. Formally it is concerned with the mechanical way in which the values of goods and of shares in distribution emerge in the market. But it has no concern with the organization of that market, the nature of the transactions which occur there, or the less immediate facts of the distribution of opportunity, property, and leisure upon which the size of these shares rest. Its explanatory terms are not matters subject to control." Ibid., 313.

12. Ibid.

13. For example Clark, Social Control Business; Sumner Slichter, "The Organization and Control of Economic Activity," in The Trend of Economics, ed. Rexford Tugwell (New York: Knopf, 1924); Dexter Keezer and Stacy May, Public Control of Business: A Study of Antitrust law Enforcement, Public Interest Regulation, and Government Participation in Business (New York: Harper \& Bros., 1930); and Morris Copeland (Ph.D. dissertation, 1921, unpublished manuscript).

14. Wesley Mitchell, Business Cycles (Berkeley: University of California Press, 1913). See also Mitchell, "Unemployment and Business Fluctuations," American Labor Legislation Review 13 (1923): 15-22, recommending "social experimentation" in unemployment relief to ease the postwar adjustments.

15. Thorstein Veblen (1898), "Why Is Economics Not an Evolutionary Science?," reprinted in The Place of Science in Modern Civilization (New York, 1919), 73; Wesley Mitchell, "The Role of Money in Economic Theory," AER 6 (March 1916): 140-61.

16. John Maurice Clark contributed to Mitchell's theory of business cycles with his explanation of the "acceleration principle," wherein changes in the economy's rate of growth place disproportionate pressure on capital goods producers as compared to consumer goods producers. See John 
M. Clark, "Business Acceleration and the Law of Demand," Journal of Political Economy 15, no. 3 (March 1917): 217-35.

17. See also Malcolm Rutherford, "Institutionalism and the Social Control of Business," History of Political Economy 47 (ann. supp.) (2015): 77-98.

18. Fried, Assault on Laissez Faire, 5-10; Kyle Bruce, "Activist Management: Henry S. Dennison's Institutional Economics," Journal of Economic Issues 40 (December 2006): 1113-36.

19. Price and Price Policies, ed. Walton Hamilton and Associates (New York: McGraw-Hill Book Co., 1938), 23.

20. See Arthur Robert Burns, "Review of Price and Price Policies, ed. Walton Hamilton and Associates," Political Science Quarterly 53 (September 1938): 425-28; Blaug, Economic Theory, 703.

21. President Wilson, "The Opportunity of the National Chamber of Commerce," Chamber Records (February 3, 1915): 78-81, 80.

22. Joseph Davies, "The Federal Trade Commission," Chamber Records, Hagley Archive, Accession No. 1960, Series I (February 4, 1915): 15563, 163. [Hereafter Chamber Records.]

23. Edward Nash Hurley, Helpful Activities to Strengthen American Business (Washington, DC: Government Printing Office, 1916).

24. Berk, Brandeis and Regulated Competition, 121-30. Hurley sent out the FTC publication, Fundamentals of the Cost System (Washington, DC: Government Printing Office, 1916); Annual Report of the Federal Trade Commission (Washington, DC: Government Printing Office, 1916), 15.

25. Paul Cherington, "Preliminary Report," Chamber Records (February 4, 1915), 347-63; Cherington, "Maintenance of Resale Prices," ibid. (February 10, 1916), 210-40.

26. "Minority Report," Chamber Records (February 10, 1916), 215-71; House Committee on Interstate and Foreign Commerce, To Prevent Discrimination in Prices and to Provide for Publicity of Prices to Dealers and the Public: Hearings, 63rd Cong., 2nd sess., on H.R. 13305, February 27, 1914-January 9, 1915 (Washington: Government Printing Office, 1915).

27. Robert D. Cuff, The War Industries Board: Business-Government Relations During World War I (Baltimore: The Johns Hopkins Press, 1973). 
28. J. Maurice Clark, Walton Hamilton, and Harold Moulton, eds., Readings in the Economics of War (Chicago: University of Chicago Press, 1918); Charles Van Hise, Conservation and Regulation in the United States During the War (Washington: Government Printing Office, 1918).

29. FTC v. Gratz, 253 U.S. 421 (1920), limiting FTC authority to prosecute antitrust abuses already deemed illegal by law or Court precedent.

30. Herbert Hoover, Chamber Records (September 19, 1917), 127-31.

31. See Brandeis, "The Democracy of Business," Chamber Records (February 12, 1914), 168-72, 168; Arthur Jerome Eddy, The New Competition: An Examination of the Conditions Underlying the Radical Change That Is Taking Place in the Commercial and Industrial WorldThe Change Taking Place from a Competitive to a Cooperative Basis (Chicago: A.C. McClurg \& Co., 1917).

32. "Progress in the Elimination of Waste," in The Fourteenth Annual Report of the Secretary of Commerce (Washington, DC: Government Printing Office, 1927).

33. Wesley C. Mitchell, "What Is Stabilization?," Chamber Records (April 29, 1931): 117-22, 118.

34. Maple Flooring Manufacturers' Assn. v. U.S., 268 U.S. 563 (1925), 574, 576.

35. William J. Barber, From New Era to New Deal: Herbert Hoover, the Economists, and American Economic Policy, 1921-1933 (Cambridge: Cambridge University Press, 1985), 2-4.

36. Ellis W. Hawley, "Herbert Hoover, the Commerce Secretariat, and the Vision of an 'Associative State,' 1921-1928," Journal of American History 61 (June 1974): 116-40; Robert F. Himmelberg, The Origins of the National Recovery Administration: Business, Government, and the Trade Association Issue, 1921-1933, 2nd ed. (New York: Fordham University Press, 1993).

37. Paul T. Cherington, "Training Industrial Secretaries," Chamber Records (February 11, 1914): 83-85, 83.

38. On the history of Harvard Business School and its changing curriculum and mission, see Rakesh Kurana, From Higher Aims to Hired Hands: The Social Transformation of American Business Schools and the Unfulfilled Promise of Management as a Profession (Princeton: Princeton University Press, 2007). 
39. Arthur E. Swanson, "The Harvard Bureau of Business Research," Journal of Political Economy 22 (November 1914): 896-900, 896. Swanson, an economics professor at Northwestern University, provided a prescient critique of the Bureau's importance. "The development by the Harvard Bureau of a distinct co-operative plan of organization for conducting business research should be recognized as a valuable contribution in itself. This plan, modified in particulars as a result of further experience, will doubtless serve as the basis for the inauguration of research activities by other institutions." Ibid., 899.

40. Ibid., 897. See also: "Systematizing Drug Store Expense," Pharmaceutical Era 47 (April 1914): 143-44.

41. Ibid., 900 .

42. Kyle Bruce, "Activist Management: Henry S. Dennison's Institutional Economics," Journal of Economic Issues 40 (December 2006): 1113-36, 1129.

43. See Edwin R. A. Seligman and Robert A. Love, Price Cutting and Price Maintenance: A Study in Economics (New York: Harper \& Brothers Publishers, 1932). This study cataloged all federal cases dealing with information sharing on prices.

44. Jeff Biddle, "Social Science and the Making of Social Policy: Wesley Mitchell's Vision," in The Economic Mind in America: Essays in the History of American Economics, ed. Malcolm Rutherford (New York, 1998), 43-79, 46. See also Mitchell, Business Cycles, 588-96.

45. Mitchell, Chamber Records (May 15, 1922), 632-39, 636.

46. Howard Sherman, "The Business Cycle Theory of Wesley Mitchell," Journal of Economic Issues 35 (March 2001): 85-97, 88.

47. Ibid., 90. Mitchell, Business Cycles (1913, 1989), 16.

48. See Wesley Mitchell, "Unemployment and Business Fluctuations," American Labor Legislation Review 13 (March 1923): 15-22, 18.

49. Herbert Hoover, Memoirs of Herbert Hoover, vol. 2 (New York: Macmillan, 1937), 41-42.

50. "Country's Business Continues to Increase," Wall Street Journal (December 8, 1921), 2. See also Barber, New Era to New Deal, 8. Hoover's Advisory Committee on Statistics included Mitchell, "Edwin R.A. Seligman ([Professor of Economics] Columbia University), Allyn A. Young ([Professor of Economics] Harvard), Walter F. Willcox ([Professor of Economics and Statistics] Cornell), Carroll W. Doten ([Professor of Economics] Massachusetts Institute of Technology), Edwin F. Gay 
(then president of the New York Evening Post, who had formerly served as the first dean of the Harvard Business School), and William S. Rossiter (formerly the head of the U.S. Census Bureau)."

51. Patrick Reagan, Designing a New America: The Origins of New Deal Planning, 1890-1943 (Amherst: University of Massachusetts Press, 1999), 72-73.

52. See Charles Merriam, The Making of Citizens: A Comparative Study of Methods of Civic Training (Chicago: University of Chicago Press, 1931), for an assessment of European state socialism that is both laudatory of its public goals and critical of the means used to achieve them. See also James Kloppenberg and Richard W. Fox, A Companion to American Thought (New York: Wiley-Blackwell, 1995), 449.

53. Reagan, Designing a New America, 75.

54. Walton Hamilton, "Affectation with Public Interest," Yale Law Journal 39 (June 1930): 1089-112. See Harry Scheiber, “The Road to Munn: Eminent Domain and the Concept of Public Purpose in the State Courts," Perspectives in American History 5 (1971): 327-402.

55. Dorothy Ross, The Origins of American Social Science (Cambridge: Cambridge University Press, 1991), 213. This is also where mainstream institutionalists departed from Veblen's use of evolutionary theory, which did not leave room for social guidance and legislative reform. See Rutherford, Institutionalist Movement, 38-39, 44; Rutherford, "Morris Copeland: A Case Study in the History of Institutional Economics," Journal of the History of Economic Thought 24 (September 2002): 261-90.

56. Hamilton, "The Regulation of Employment Agencies," Yale Law Journal 38 (December 1928): 225-35; Hamilton, "Affectation with Public Interest"; Hamilton, "The Control of Big Business," The Nation 134 (May 25, 1932): 591-93. See also Clark, Social Control of Business.

57. Sumner Kittelle and Elmer Mostow, "A Review of the Trade Practice Conferences of the Federal Trade Commission," George Washington Law Review 8 (1939-1940): 427-51.

58. William Novak, "A Revisionist History of Regulatory Capture," in Preventing Regulatory Capture: Special Interest Influence and How to Limit It, ed. Daniel Carpenter and David Moss (The Tobin Project, 2013). 


\section{Author Biography}

Laura Phillips Sawyer is an Assistant Professor in the Business, Government, and International Economy Unit at Harvard Business School. Laura's work has appeared in Business History Review, Journal for the Gilded Age and Progressive Era, and Capital Gains: Business and Politics in the 20th Century (2016). Her book American Fair Trade: Proprietary Capitalism, Corporatism, and the "New Competition," 1890-1940, has been recently published by Cambridge University Press. 